\title{
Use of Zaltman Metaphor Elicitation Technique (ZMET) To Analyze Brand Gap Case Study on a Footwear Company - BATA, India
}

\author{
Priyanka Soni, Arushi Jamaiyar
}

\section{Introduction}

Brand image is the set of beliefs that a customer carries for a particular brand. It is the psychological output that all companies want to achieve after the extensive branding exercises that they carry out. However, the most important part of any branding process is to create a brand identity. Brand identity, as coined by Kapferer, is what the company wants to project to the consumers through its physicality, i.e. brand, design logo, pricing and its emotionality, which is the emotional attributes the company attaches to its product. This process in turn creates a certain position of the brand in the form of a distinct space in the consumer's mind. Positioning is hard to achieve, but once positioned, repositioning is even tougher. How much successful the company has been in its endeavor can be gauged by analyzing the brand gap, which is the difference between brand identity and brand image. There are many tools to analyze the brand gap. Zaltman metaphor elicitation technique (ZMET) is one of them. ZMET was developed by Dr.Gerald Zaltmanof Harvard Business School in early 90s. This technique explores the non-literal expressions of people to bring out both conscious and especially unconscious thoughts in order to have better understanding of the brand. It involves collection of visual images along with personal interviews that helps create an overall picture of what the consumer thinks about the brand in question.

The purpose of this case study is to develop a customer perspective analysis using ZMET to find out the brand gap in case of Bata and how has repositioning has affected it. For this, the present positioning of BATA in the footwear industry has been analyzed and the repositioning steps adopted by it have been elucidated. This has been followed by an extensive ZMET on a sample of people with different demography, age groups and gender. The understanding of consumers' impressions of Bata repositioning and the meanings that they associate with have been enhanced by our cross case analysis.

\section{Company Overview}

Bata is one of the largest brands in the Indian footwear market that has been carrying out various repositioning strategies recently. Over the years it has established itself as a trustable and reasonable brand. In the initial years, Bata was the sole leader of the footwear market but with time it started losing its share as new players like Reebok, Liberty, Nike etc. entered the industry, giving the brand a tough competition with their fancy designs and enormous variety. Also, the growing popularity of the unorganized footwear section hit hard on the company. This provoked Bata to reposition itself and change its brand image.

In this case, Bata has positioned itself as a conservative yet trusted brand in the customer's mindset but owing to the stiff competition from the designer footwear, wants to capture the potential youth market by renovating. In wake of this, Bata has incorporated many changes in its brand identity and subsequent strategies to reposition itself. And the process is still going on.

\section{Indian footwear market overview}

Recently, dynamic Retail service and the process of Globalization led to a massive transformation in Indian Footwear Industry. De-licensing of the market allowed expansion and introduction of large number of International brands, providing a scope for substantial growth in industries.

India globally stands second in reference to the production of Footwear Industry and contributes more than $13 \%$ of the production of footwear in the world. Of 2065 million pairs of footwear production, leather footwear proportion was about $49 \%$ and non-leather footwear constituted the remaining $51 \%$ in the year 201213.Almost $95 \%$ of the production was to fulfil the demands of domestic market. The Indian footwear market is expected to grow at a high rate of more than $20 \%$ by 2015 as compared to the previous annual market growth rate of $15 \%$.

In 2012 , almost $70 \%$ of market share was in the hands of unorganized sectors and the remaining $30 \%$ share was under organized sector. Unorganized sectors include all the small manufacturers while the organized sectors comprise of big companies or brands like Reebok, Bata, Nike, Adidas, and Action etc. The organized sector is growing at present at the rate of $10-15 \%$ and is expected to increase. 


\section{Opportunities and challenges}

At present, the organized sector is growing at the rate of 10-15\%.The major segment ( 60\%) of market comprise of men's footwear mainly leather products. However, the rapid growth in women and children segments are attracting many marketers now-a-days. Recently, Bata launched a brand 'Sundrops' to attract women's segment. Many International Brands are joining forces with Domestic brands because of low raw material cost and cheap labor. E-retailing and low per capita consumption are generating a huge opportunity for footwear industries to grow.

The Chinese Products and other unorganized sector products however offer a tough competition in front of these industries. Also lack of distribution channels and government taxes lead to an increase in the price of product by almost $30 \%$.

\section{Bata in market}

Over many years, Bata has established itself as a Trusted Family Brand. It has been ruling in the Indian market for many years and thus people attach a national feeling to the brand. Initially known for its products for the middle class, Bata, now has started focusing on the upper class also. Earlier mainly leather products were available in the store but now due to inclusion of brands like Hush puppies, Marie Claire etc. Bata's product series has improved. Now it has started to avail products for all segments \& caters to all age groups.

Bata is one of the largest brands with more than 1200 outlets across India. But until recently, it has been facing tough competition from many designer brand like Nike, Adidas and many Chinese local products. It has always been seen as a conservative brand by the consumers. This is the result of a solid positioning of the Italian brand in the minds of the consumers who see it as a very reliable brand close to their heart. However, it has started losing eyeballs to the new players.

\section{History}

BATA, a company that has been ruling the Indian footwear industry for several decades and has been closely attached with the Indian sentiments of faith and reliability, is actually of Czech origin. It was founded in 1894 by three siblings, Tomas Bata, Antonin Bata and Anna Bata, belonging to a family of cobblers. The company was originally leather based and ran on the traditional model of a single owner workshop. Then, in 1895, due to financial constraints, Tomas Bata started sewing shoes from canvas which was widely accepted and helped the company grow. Continuing with the innovations, in 1904, Bata came up with its first mechanized mass product - "Batovky", a leather and textile shoe. This product was highly appreciated for its simplicity, quality and affordability. By 1912, Bata had grown into one of the largest mass producers of shoes in Europe, producing 2200 pairs per day.

BATA occupied a respectable position in the consumer's mind and enjoyed a monopoly till the 1980 s. During1988-89, it launched the sports footwear line under "Adidas", marketed "Star" clothing and came up with a new brand "Tigre". Sticking to its motto of continuous renovation, BATA carried out a lot of research and development activities. It replaced insole leather by introducing the special leather board. This was followed by the installation of an efficient 18-station bicolor injection molding plant at Bangalore. This factory produced "State-of-the-art" injection molded shoes with synthetic and textile uppers and soleing material made up of PVC compounds. Today, Bata India is the largest footwear-selling Company for Bata Shoe Organization and is making second largest Revenue, approximately $15 \%$ of BSO revenue. It has a huge market share in organized sector $(\sim 16 \%)$ and earns almost $99 \%$ of its revenue from domestic market. Every day, Bata provides shoes to 1.5 lakh customers and makes a huge profit every year by selling 50 million pair of shoes

At present, the company has more than 1500 Bata Shoe Stores located in over 500 cities across India and planning to open more in the coming years. It has 30 exclusive outlets for retailing Hush Puppies range of shoes.

\section{Need for repositioning}

There were a number of reasons which lead Bata to reposition its brand identity. Bata wanted to change its image from a production centric brand to a fashionable and stylish brand. The reasons for it were:

1) Conservative brand identity - Due to its conservative designs and only dark color leather products BATA was not able to connect with the youth. Generally youth like bright colors, funky and cool designer stuff which BATA was missing. There were very few variations in designs and all the products look the same. So, It was not considered fashionable and the product line was bad.

2) Competitors: There are large number of players in competition with BATA. Chinese Products offer very cheap materials for the lower incomegroups and other designer brands like - Nike, Adidas, metro, heels etc attract all the creamy layers of the society.

3) Advertising and Promotions: Bata never went for TV commercials and advertising and promotional schemes. It affected badly the awareness of BATA among people. Even there were new products people didn't knew about it. It did not have a full-fledged advertising strategy even in media or newspapers. It does 
minimal promotions like few newspaper ads and no brand personification like brand ambassadors or jingles or mascots.

4) Lack of Visual Merchandise - It has not enough hoardings, no music playing inside store, and even not a good ambience. People coming for shopping didn't get the feeling from inside of buying the products. Thus there was a lack of Stimuli-Response factor.

5) Communication Gap: There isaLack of communication between customer and companywhich leads to an absence of customer dealing experience. The store has very less staff to guide the Consumer. So, there were many customers who go back as they were unattended.

\section{Repositioning Strategies}

1) Expansion of Stores to attract Mass Customers Market

Bata India has a strong brand equity and holds a market share of approximately $16 \%$ in the organized footwear segment. It has 1,388 stores which is widely distributed in the entire networks of Market.

2) Retail Network:

Approximately $85 \%$ of Bata revenue comes from retail network. Non-retail channels (dealers/institutional/industrial sales) constitute $14.2 \%$ of its total revenue and balance is driven through exports

\section{3) Customer Segment:}

Bata is focusing on women, youth and child footwear segment to increase their contribution in driving Bata revenue. Across all stores, it has enhanced the number of display areas to attract new trendy design loving children and women under brands like Marie Claire, Hush Puppies, and North Star etc.

\section{4) Premiumization:}

To enhance the value-mix, Bata is recently concentrating on high-margin leather segment accessories like ladies bags, Belts etc. Company intends to increase sales per store by improving value mix with a focus on with Bata shoe organization having a market share of $20 \%$ worldwide in the footwear industry, Bata focusses on the need of expertise and technology for defense as well as Industrial shoes

\section{Analysing The Present Brand Image Of Bata By Implementing Zmet}

The Zaltman metaphor elicitation technique (ZMET) is a technique which brings out the conscious as well as unconscious thoughts through metaphors or figurative expressions collected by people. The method was first introduced by Dr. Gerald Zaltman. There are many things that keep on going in our mind still we are not aware of .The technique helps in acquiring the hidden-knowledge to get to know about all the emotions that people don't know in their conscious mind

\section{Data Collection Methodology:}

A total collection of 18 people has been interviewed out of which 8 people belong to age group above 30yrs and 10 people belong to age group 18-30. The people were asked to collect some figurative expressions or images containing a particular idea to reflect the image of brand Bata in their mind. The steps taken are as follows:

1) Storytelling: Each image has to be described using some story or event

2) Missed Images: Images which people find difficult to find are asked

3) Sorting Task: Sorting of all the images into different groups like thrill, safety etc.

4) Construct elicitation: Random selection of any three image and asking questions of how two of the images are different from the third one. The process of random selection of three images is continued until a new construct is extracted

5) Most Representative Picture: People indicate which picture among all their images best describe the brand

6) Opposite Images: Indication of image that represents just opposite of what they think about the brand

7) Sensory Images:Other non-visual sensory images are asked with reference to brand

8) MentalMap: All the constructs made using discussions are reviewed and people are asked if any idea interviewer is missing.

9) SummaryImage: Digital imaging technique is used to create an overall image of brand with the support of a technician 10) ConsensusMap: A map is constructed using those constructs that are important for marketing purpose.

Researchers use constructs, metaphors, construct-relationships and images to describe the perspective of customers towards any Brand

Constructs: It is a label used to describe the feelings of customer towards a Brand. Constructs include expressions like concepts, ideas, emotions, value, thoughts and feelings that are of significant importance to the customers. 
Metaphors: Metaphor represents all those which we can use to interpret one thing with respect to other. In this technique, we use visual images, sensory images, constructs and their relationships.

Construct-relationship: This is used to show dependency of one construct over the other. All the constructs are not independent and there exist a relationship among them.

Images: Images reveal the feelings or thoughts that customers have with respect to a Brand. These images can be a metaphor or can take some other forms related to sense of touch or smell.

\section{Relationship between Brand Identity, Brand Image and Brand Gap:}

Brand Identity involves all those strategies that are needed to make a brand distinguishable from other brands. It reflects how a company wants to project itself in the minds of customers. Brand Identity consists of three aspects: Personality, Positioning and Brand Communication.The outcome of the Brand positioning is Brand Image which shows how brand is perceived by customers in their minds. Every Individual views a brand differently and develops different images on the basis of their life-experiences and some specific features. A positive Brand Image indicates a unique connection to a brand. A brand has a power to influence the customer's purchase related decisions. Brand is a post-purchase differentiator and helps customer in making easy and fast decisions. The difference between Brand Identity and Brand Image is Brand Gap. Brand Gap determines how successful a brand is in reflecting its identity in the minds of customers. The larger the gap is, the more the brand is lagging behind in communicating its identity to the customers.

\section{Zaltman Analysis}

Constructs mentioned by the Samples

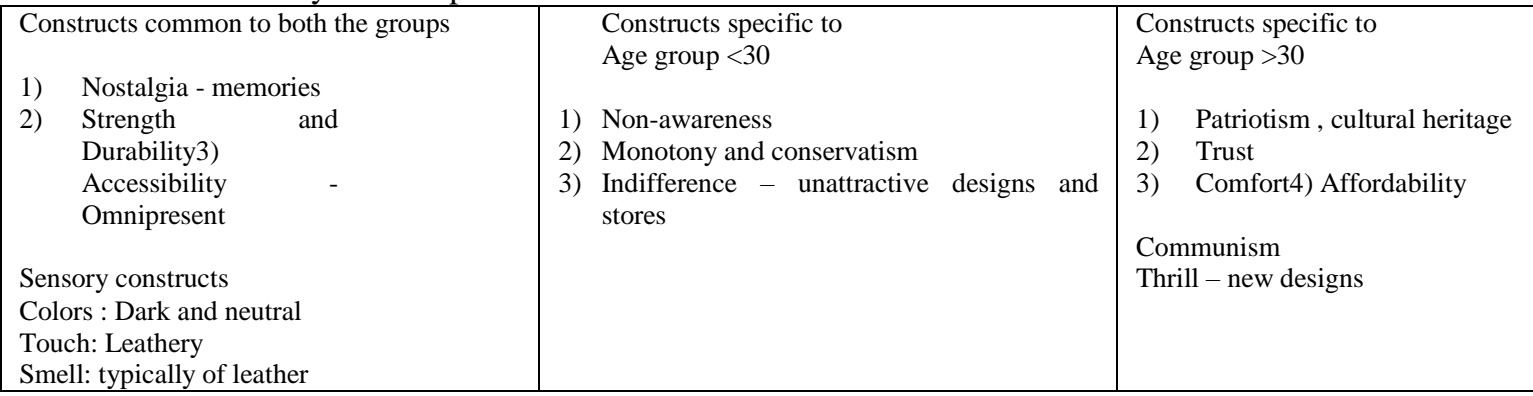

Construct relationships mentioned by the samples

\begin{tabular}{|c|c|c|}
\hline $\begin{array}{l}\text { Constructs } \\
\text { commonto } \\
\text { both the } \\
\text { groups } \\
\text { 1) Nostalgia - Childhood memories, } \\
\text { family trips. } \\
\text { 2) Strength - Longevity , ruggedness - } \\
\text { trust } 3 \text { ) Accessibility - local family } \\
\text { stores - widely } \\
\text { distributed channels } \\
\text { Sensory } \\
\text { 4) Dark colors - typical conservative, } \\
\text { 4) Leathery touch - mainly leather shoes } \\
\text { 6) Smell - new shoe smell, leathery }\end{array}$ & $\begin{array}{l}\text { Constructs specific to } \\
\text { Age group <30 } \\
\text { 1) Non awareness - Lack } \\
\text { of advertisements, } \\
\text { publicity. } \\
\text { 2) Monotony - uniform } \\
\text { designs, non- } \\
\text { versatility } \\
\text { 3) Communism --- attitude } \\
\text { of sales agents - } \\
\text { government institutions }\end{array}$ & $\begin{array}{l}\text { Constructs specific to } \\
\text { Age group }>30 \\
\text { 1) Patriotism - nationality , rich brand } \\
\text { heritage } \\
\text { 2) Trust - durability , brand name- } \\
\text { loyalty } \\
\text { 3) Comfort - loyalty } \\
\text { 4) Affordability - middle class -- } \\
\text { discounts, sales } \\
\text { 5) Thrill --- fond of new designs, } \\
\text { durability - childhood memories }\end{array}$ \\
\hline
\end{tabular}

Features of all constructs

1) Nostalgia: The construct here was common to most of the participants. BATA reminds them of their childhood, family, special occasions. Most of them recalled the white and black kets, shoe polishes.

YP18: "It brings back memories of school, especially the advertisement of BATA: Best naughty boy of school "

OP8: "We used to visit the stores with our parents to buy new shoes "

OP2: "I was reminded of my marriage as I had bought a blue sandal then."

2) Durability: Another construct that was supported by many. BATA shoes in general are perceived by many to be rugged, durable and strong. This builds a trust for the brand.

OP1: "My father used to wear the Ambassador shoes that lasted for years."

YP10: "Our school shoes did not tear off even when we played rough games like football "

OP8: "BATA shoes are very reliable and affordable" 
3) Accessibility: This construct had a good support from both the groups. Participants said that they have come across many stores in the country and thus they are very common.

YP17: "I miss my home when I think of BATA as we had a family store just down the lane."

OP9: "You never run out of the stores. SO no need to worry if you break your shoe."

4) Patriotism: The older set has seen BATA since independence when it was almost a monopoly. Also since it has a rich cultural value and an even richer brand heritage, they associate a feeling of nationality with it. OP1: "the sales staff is very friendly and converse in the local languages like Bengali, Bhojpuri and other dialects."

OP2: "I am reminded of people wearing chappals of BATA and not using other international brands. It makes me feel proud."

5) Comfort: This construct was sited mainly by the people of the age group $>30$. Traditional BATA shoes along with new additions like Hush Puppies, DrScholls are considered to be very comfortable.

OP8: "DrScholls is a great product line and it provides relief to my sole pain"

6) Affordability: Considered to be a deciding factor while buying any shoe, BATA seems to excel in this area for the upper age group people. Since long it has jelled perfectly with the middle class families.

OP13: "Shoes, though being conservative are cheap as compared to their quality."

OP14: "They provide a value for money"

7) Trust: This construct is important for the older generation as they have been watching their parents and other buy these shoes. Also, the durability and heritage helps build a trust in them, thereby creating a brand loyalty.

OP1: "BATA shoes till now are reliable. My whole family is a big fan of it."

8) Thrill: Interestingly, many people belonging to the older group still find it thrilling to go to a BATA store as it brings good vibes to them.

OP8: "We used to go to buy shoes with our parents are used to be very enthusiastic about it."

9) Fond of the designs: This construct represents loyalty in some ways. This idea was supported by the age group $>30$.

OP1: "There is something very unique about BATA. The products Jugli, Miss Mary were very popular. The booties even exist now."

OP14: "I used to buy the typical maroon shoes. Also, I still love the purses it has to offer."

10) Non awareness: Surprisingly, despite doing a lot of repositioning, the youth is still mostly unaware of the new designs as according to them there is not enough publicity of the brand.

YP11: "I don't remember seeing any advertisements of BATA and would love to watch some"

YP 12: "BATA hardly comes to my mind whenever I go for shopping."

11) Monotony: Most of the participants from the younger age group found the designs boring, non-versatile and uniform. They still associate it with the past, their parents or forefathers wearing these shoes. They do not share a brand recall for BATA. That is, they do not think of the brand much while they are out for shopping.

YP6: "I find it orthodox and conservative. No new designs are available."

YP18: "I can buy formal shoes from this brand but for sports shoes I would prefer Nike or Reebok."

12) Communism: For the younger set, the stores look unattractive and ancient with the sales staff not very friendly. According to them, they represent typical government institutions and the sales people do not outwardly approach them or guide them towards selecting a product.

YP16: "The stores do not really have an aesthetic appeal and I don't feel like visiting it when I am with my friends."

YP17: "I would prefer going to Reebok, Nike or other big brands as they have a large collection and the staff is interactive."Sensory constructs:

13) Dark colors: Most of the participants showed pictures of maroon, black and brown colors. This reflects uniformity in the designs.

YP4: "You do not find bright colors in the stores though they have started coming with some."

OP13: "I like the muted colors of BATA. They are perfect for formal shoes and daily wear. They go with all the dresses."

14) Leathery touch: Participants could not exactly pinpoint the touch they experience but more or less majority of them were reminded of the touch of leather.

YP12: "When I think of BATA, I think of black leather shoes"

15) Smell: Similar to eh previous construct, people started thinking of a typical smell of a new shoe. Also, they were reminded of the smell of leather.

YP11: "I do not know why but the shoes smell to me like silica gel."

OP14: "the typical smell when you enter a shoe house. BATA has a distinctive smell and bring me down the memory lane." 


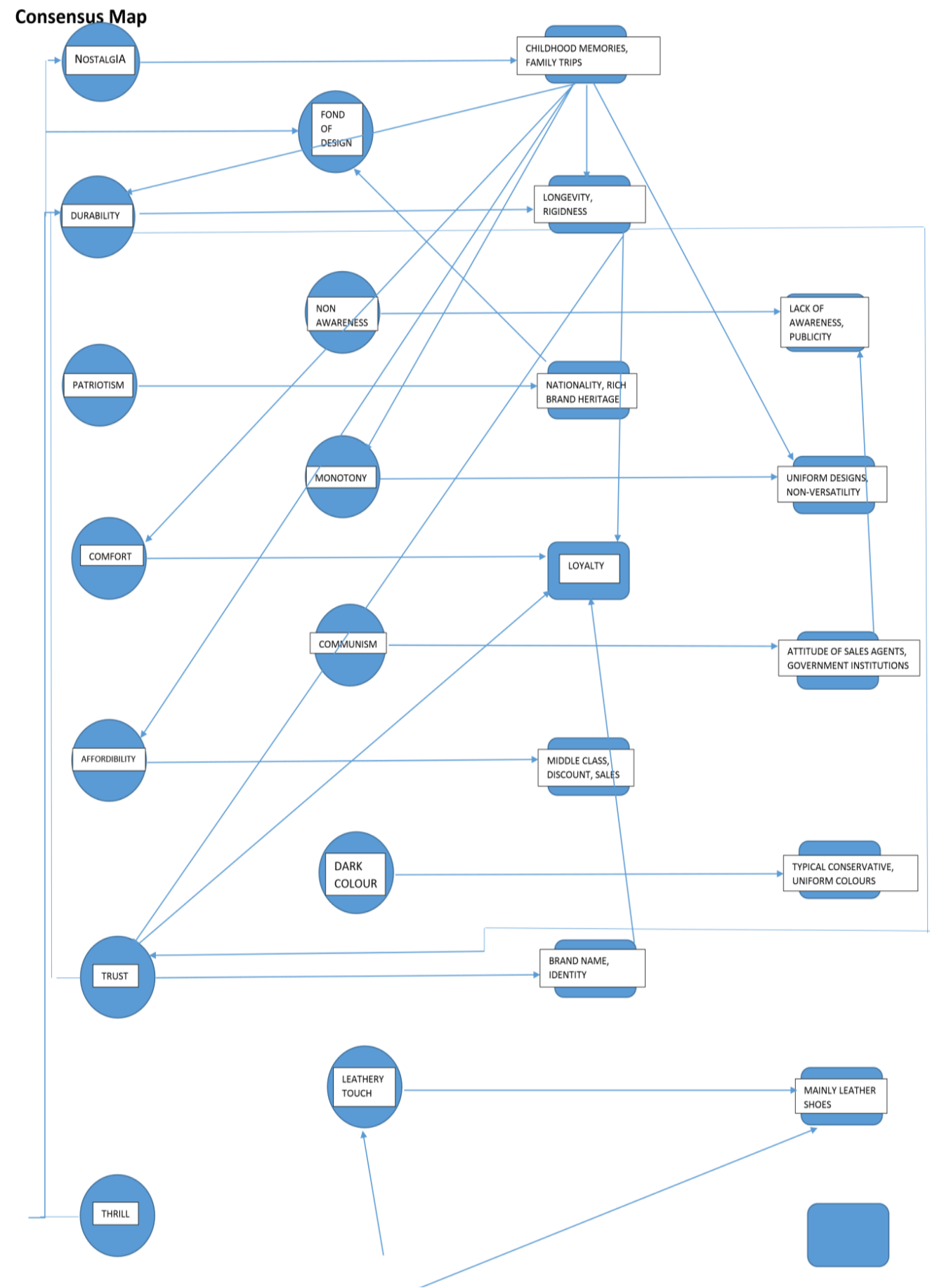

ZMET Dictionary

A compilation of the pictures given by the sample formed into a dictionary in order to describe each construct 1) Nostalgia

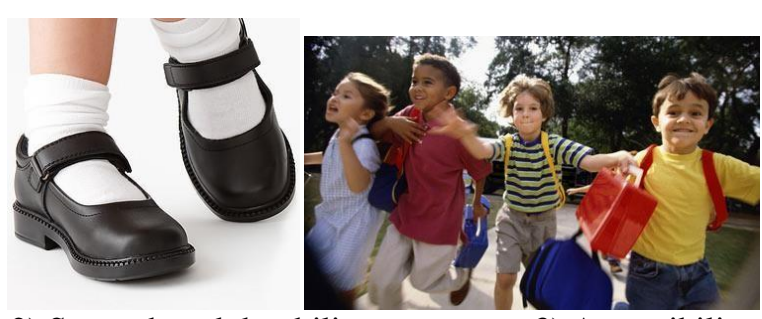

2) Strength and durability 3 ) Accessibility 


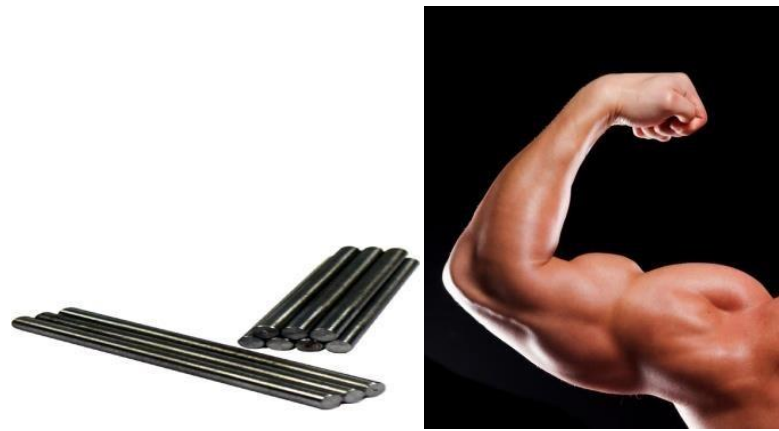

4) Affordability

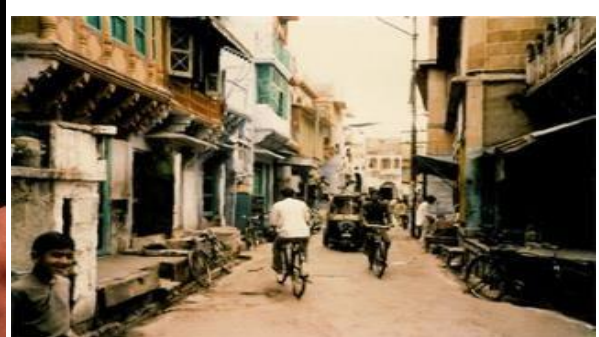

5) Trust

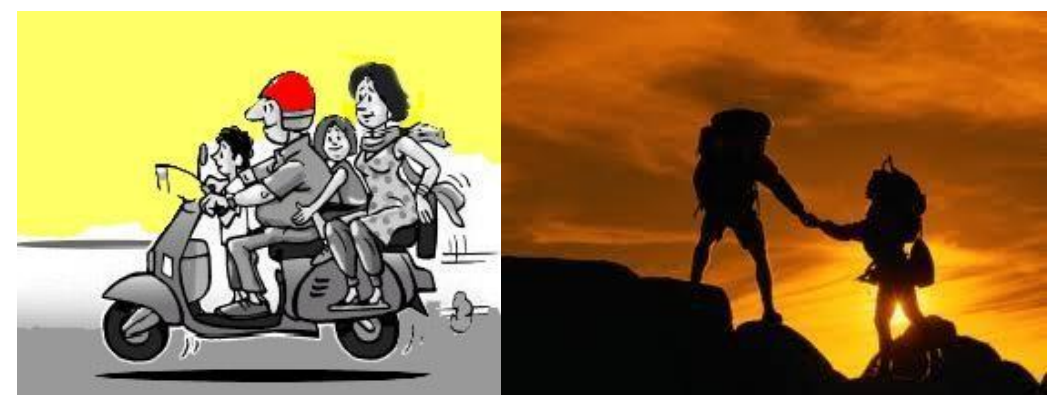

6) Thrill - new designs
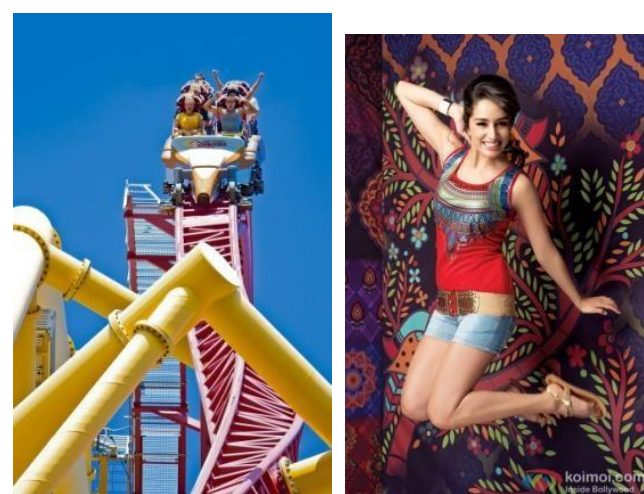

7) Patriotism

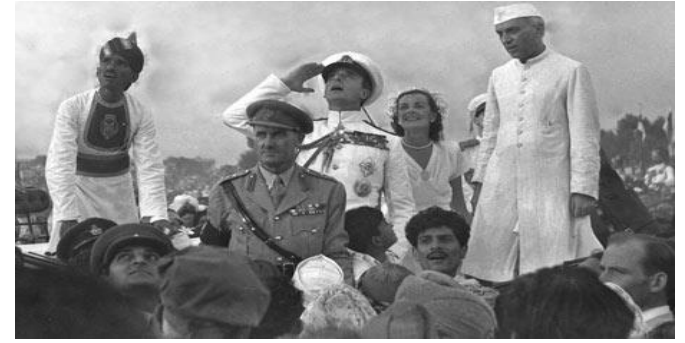

8) Conservatism

9) Indifference

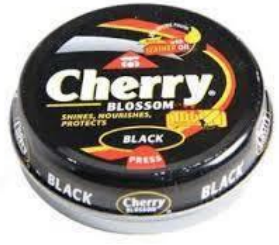

9) Comfort
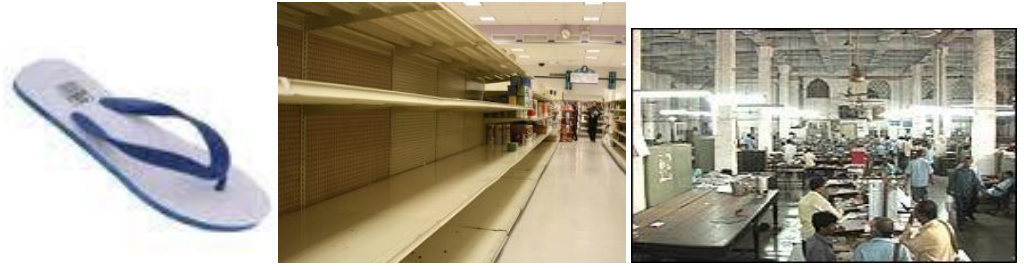

10) Smell and touch 

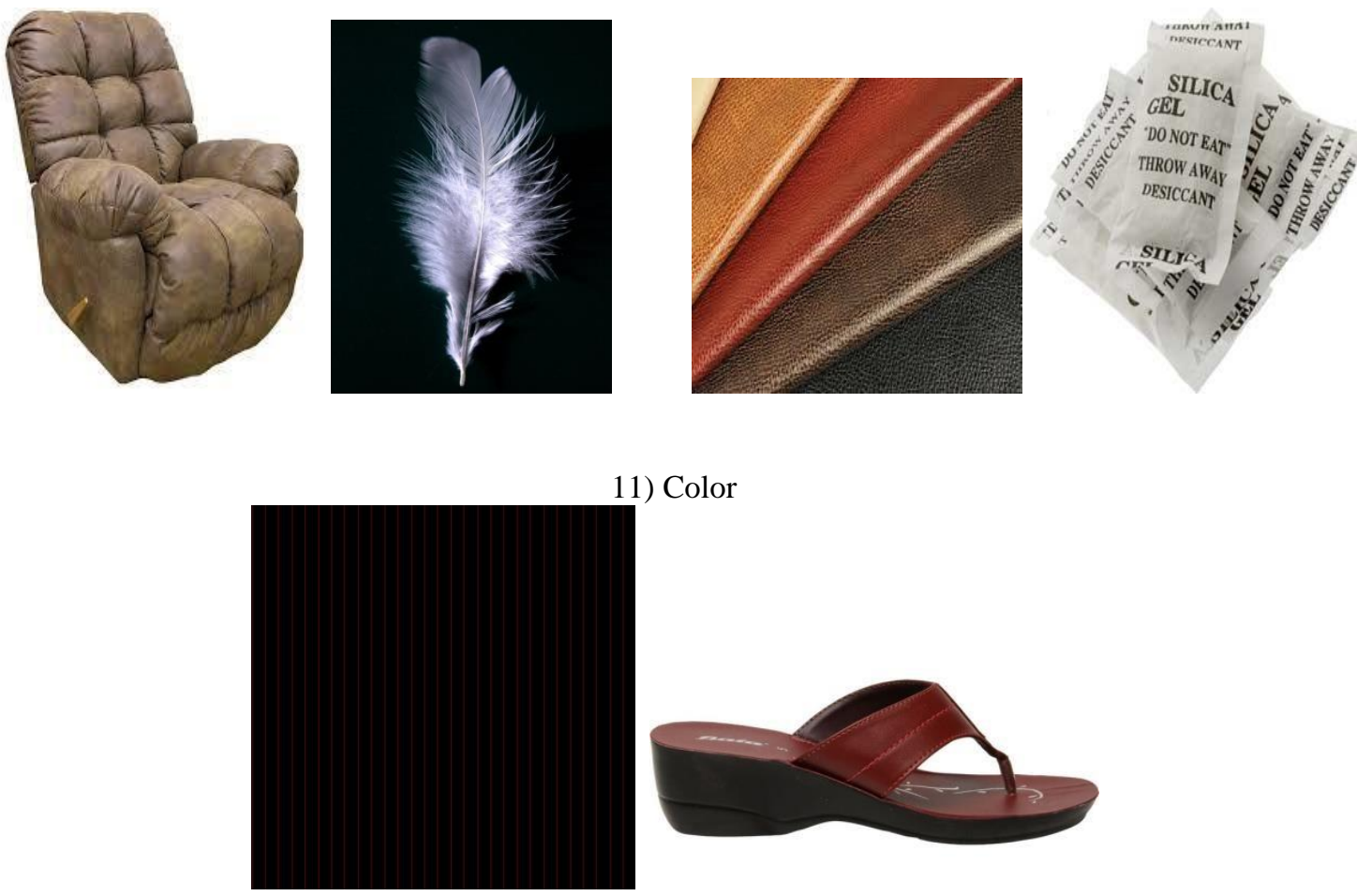

\section{Brand Identity}

As has been discussed earlier, Bata has always wanted to project itself as a reliable brand with its products being affordable and sturdy. But it has mostly been product centric with the targeted segment being mainly the middle class mid-age group, especially the male section. But now, it has revamped its strategies by trying to cover all age groups and genders, especially the youth. Once known as a manufacturing company, is planning to change its brand image to a marketing company. As mentioned already, Bata India has introduced a deep level of penetration in footwear product line and is emphasizing more on quality services. It wants to project itself as a a fashion conscious brand and is primarily focussing on women, youth and child footwear segments.It aims to depart from a lower end segment to upper and middle-class segment. Various new designer brands like Hush Puppies and Marie Claire has been launched to attract a large proportion of market share.

\section{Brand gap}

On carrying out the ZMET analysis, it can be observed that though some attributes like strength, durability and accessibility are common between the two groups, there are many constructs in which these two differ. Bata enjoys a high degree of trust and preference amongst the higher age group people. They connect themselves with Bata well, most of them relating it to their childhood days or some special occasions. It brings in them a sense of nostalgia. Apart from these emotional attributes, the brand in itself means comfort and affordability to them. However, a smaller chunk of the population does not like the same old designs and the ones belonging to the higher income group do not seem much enthusiastic about buying Bata shoes as it does not offer a good variety. Apart from this dissonance, there is not a lot of brand gap in this particular segment as the brand occupies a good hold among people of this group.

However, the stark difference of brand identity and image comes from the analysis of the younger generation. Most of the youth interviewed do not prefer Bata and are also unaware of the revamp that it has been carrying out in its designs.Ironically, the youth also relate their childhood memories with these shoes but this emotionality does not play a huge role when they purchase their shoes now. They consider Bata to be monotonous uniform and boring, with very less variety and choice, especially in the fashion or sports footwear section. For them, Bata is a brand for the older generation, sturdy and durable, and hence can be considered for purchase of formal shoes. There is thus, a huge brand gap in this segment which is a challenge for Bata.

\section{References}

[1]. Dr Gerald Zaltman for introducing the ZMET method

[2]. "Revealed Bata's secret to attract the fashion conscious"-RediffRealtime

[3]. "Bata trying to reposition its image "-Times of India

[4]. "Rebooting Bata:Will its new campaign help the footwear brand get there" - Economic Times

[5]. "Bata-our History"-www.bata.com 
[6]. "Bata-India ltd, company info"-Economic Times

[7]. "Bata Report"-Motilal Oswal,2005-12

[8]. "Bata-The World moves on your feet"-by gakarerakesh

[9]. "Bata set for rapid expansion; to open 70-100 stores a year"-Economic Times

[10]. "Bata launches brand new"where life meets style" marketing campaign"-Exchange4media News service

[11]. India Retail News and Research,"Result of Bata's Transformation Analysis",2009

[12]. India Retail News and Research,"Bata Tranformation-stage1”,2009

[13]. "The world at its feet", Business Today,2012

[14]. "Resurgent Bata India gets expanding at break neck speed"-Economic Times 